\title{
Geology
}

\section{Direct calibration of salt sheet kinematics during gravity-driven deformation --Manuscript Draft--}

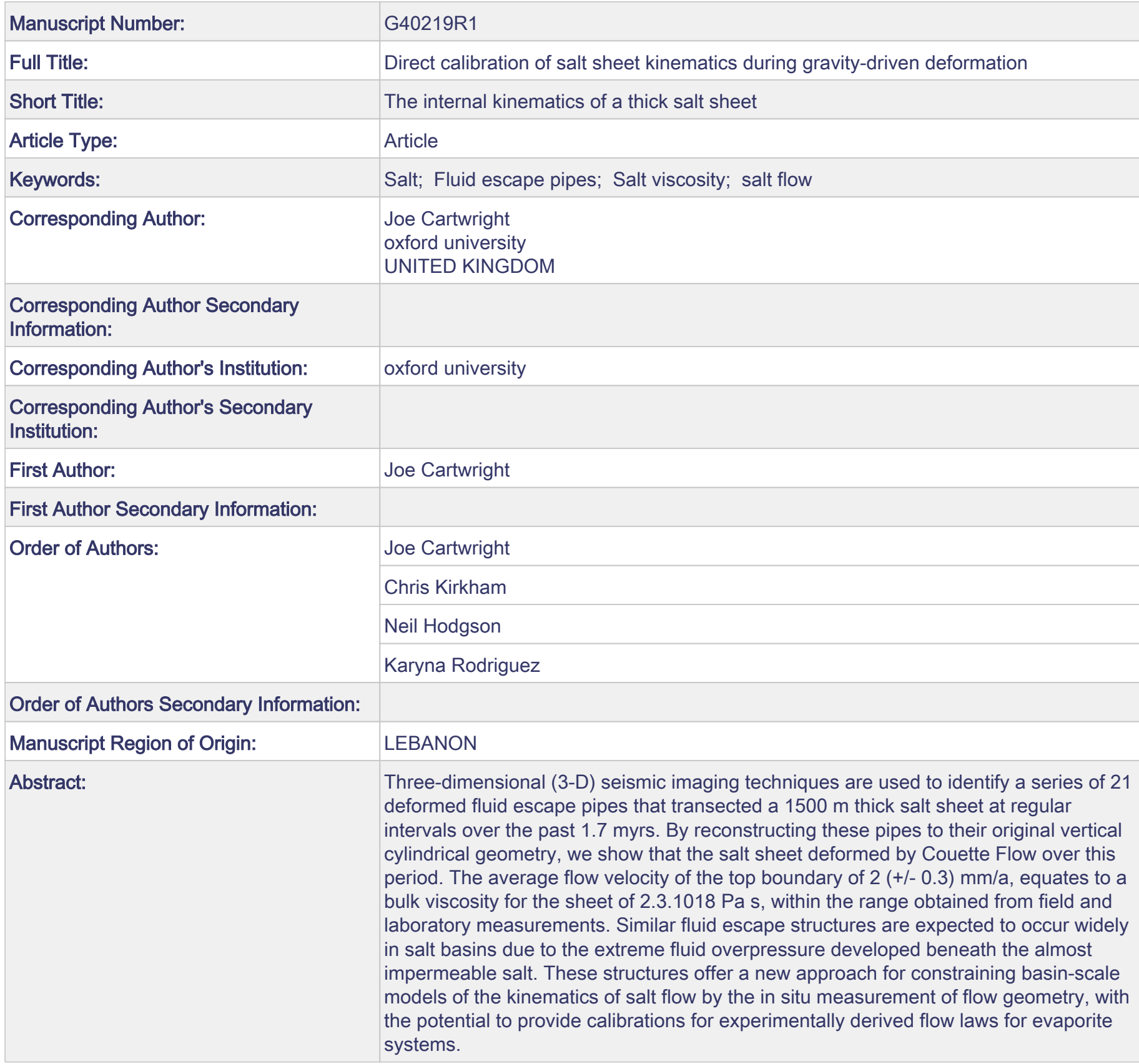


Publisher: GSA

Journal: GEOL: Geology

DOI:10.1130/G40219.1

\section{Direct calibration of salt sheet kinematics during gravity-}

\section{2 driven deformation}

3 Joe Cartwright ${ }^{1}$, Chris Kirkham ${ }^{1}$, Claudia Bertoni ${ }^{1}$, Neil Hodgson ${ }^{2}$, and Karyna

$4 \quad$ Rodriguez $^{2}$

$5 \quad{ }^{1}$ Department of Earth Sciences, University of Oxford, Oxford, OX1 3 AN, UK

$6 \quad{ }^{2}$ SpectrumGeo Ltd. Dukes Court, Woking, Surrey, GU21 5BH, UK

\section{ABSTRACT}

8 Three-dimensional (3-D) seismic imaging techniques are used to identify a series

9 of 21 deformed fluid escape pipes that transected a 1500 m thick salt sheet at regular

10 intervals over the past 1.7 myrs. By reconstructing these pipes to their original vertical

11 cylindrical geometry, we show that the salt sheet deformed by Couette Flow over this

12 period. The average flow velocity of the top boundary of $2(+/-0.3) \mathrm{mm} / \mathrm{a}$, equates to a

13 bulk viscosity for the sheet of $2.3 \cdot 10^{18} \mathrm{~Pa} \mathrm{~s}$, within the range obtained from field and

14 laboratory measurements. Similar fluid escape structures are expected to occur widely in

15 salt basins due to the extreme fluid overpressure developed beneath the almost

16 impermeable salt. These structures offer a new approach for constraining basin-scale

17 models of the kinematics of salt flow by the in situ measurement of flow geometry, with

18 the potential to provide calibrations for experimentally derived flow laws for evaporite

19 systems.

20 INTRODUCTION

21 Kilometres thick, autochthonous salt sheets are widely developed in the

22 geological record, and their gravity-driven deformation has had a major influence on 
Publisher: GSA

Journal: GEOL: Geology

DOI:10.1130/G40219.1

23 controlling the structure and stratigraphy of many passive continental margin, rift and

24 foreland basins, from the Proterozoic to the Recent (Jackson and Hudec, 2017). Testing

25 the contrasting modes of salt sheet flow regime (e.g., Poiseulle versus Couette) and

26 relating them to the driving and boundary conditions is a major goal of salt tectonics

27 (Brun and Fort, 2011) and has major practical implications for safe drilling through salt

28 (Weijermaars and Jackson, 2014). Accurate modeling of salt sheet behavior therefore

29 clearly requires realistic input of the salt rheology (Gemmer et al., 2004).

30 To date, no direct in situ measurements of viscosity from basin-scale deforming

31 salt sheets have been made over an appropriate time scale (i.e., millions of years) that

32 would characterise the effective rheology of the natural salt system, although attempts

33 have been made to invert for the rheology using numerical modelling (Li et al., 2012).

34 Direct measurements of salt flow velocity have thus far only been made on human

35 observation time scales using surface measurements, and only then on extrusive salt

36 bodies and salt diapirs rather than autochthonous salt sheets (Jackson and Hudec, 2017).

37 Here, we present the first direct calibration of the internal flow velocity of a thick

$38(>1.5 \mathrm{~km})$ salt sheet deforming under gravity. This allows us to compute the shear strain

39 rate and the dynamic viscosity for a 2 Myr long period of continuous flow. This

40 measurement resulted from the identification and three-dimensional mapping of a series

41 of 21 fluid escape pipes, intruded through the salt sheet episodically during its

42 deformation. We propose that fluid escape pipes represent a new class of geological

43 strain marker, and suggest that they may be widely developed in other basins with thick

44 evaporite layers. This new class of strain marker has the potential to provide constraints 
Publisher: GSA

Journal: GEOL: Geology

DOI:10.1130/G40219.1

45 on salt sheet deformation that should help refine existing numerical models of salt

46 tectonics more generally.

\section{Geological Setting}

48 The study area is in the Levant Basin, where a c. $1.5 \mathrm{~km}$ thick Messinian

49 evaporite sequence deposited during the Messinian Salinity Crisis (MSC) floors much of

50 the deeper part of the basin (Gradmann et al., 2005)(Fig. 1). Marginal uplift and

51 differential loading has led to widespread salt flow, with lateral extension around the

52 basin margins and lateral contractional salt tectonics in the basin center (Cartwright and

53 Jackson, 2008) (Fig. 1B). Bulk strain is relatively low $(<10 \%)$ in both the extensional

54 and contractional domains with limited diapirism or dissolution of the salt (Fig. 1D). The

55 internal structure of the deformed salt is well imaged by a set of laterally correlatable

56 seismic reflections generated by thin clastic inter-layers (Feng et al., 2016)(Figs. 1C and

57 D).

58 Gravity tectonics detaching in the thick salt sheet commenced in some areas

59 during the latest Messinian (Bertoni and Cartwright, 2007; Gvirtzman et al., 2013; Feng

60 et al., 2016), followed by a second phase in the Late Pliocene (Cartwright et al., 2012).

61 The gross kinematics of WNW directed, basinward flow of the salt during this latest

62 phase of deformation was orthogonal to the strike of the extensional faults and minor

63 folds developed within the clay-dominated post-Messinian sequence (Fig. 1B and 1D).

64 This regional flow regime for the eastern margin of the Levant Basin is consistent with

65 gravity tectonics driven by basinward tilting of the margin combined with an element of

66 differential loading between the slope and basin floor (Cartwright and Jackson, 2008;

67 Gvirtzman et al., 2013). Rapid loading and unloading during and immediately after the 
Publisher: GSA

Journal: GEOL: Geology

DOI:10.1130/G40219.1

68 MSC led to widespread focused fluid escape from highly overpressured pre-salt

69 sequences (Bertoni et al., 2017). This fluid escape resulted in numerous mapped

70 examples of dissolution collapse structures, mud volcanoes and fluid escape pipes,

71 identified throughout the Eastern Mediterranean using two-dimensional (2-D) and three-

72 dimensional (3-D) seismic data (Reiche et al., 2014; Kirkham et al., 2017).

\section{3-D Seismic Imaging of Fluid Escape Structures}

\section{Seismic Database and Interpretation Methodology}

75 The three dimensional multichannel reflection seismic data used in the study were

76 acquired by Spectrum in 2014, and covers an area of $5350 \mathrm{~km}^{2}$ of the Lebanese

77 continental slope between water depths of 1750 and $2050 \mathrm{~m}$. Seismic interpretation was

78 performed using Schlumberger's Petrel 3-D seismic software platform. Horizons were

79 picked manually and auto-correlated and used to generate root mean square (RMS)

80 amplitude maps. Coherence and RMS amplitude volumes were computed and interpreted

81 in time slice form to identify key structural and fluid-related features based on recognized

82 interpretational analogues (Cartwright and Santamarina, 2015; Kirkham et al., 2017)(see

83 Data Repository).

\section{$84 \quad 3-D$ Seismic Interpretation}

85 We identified a previously unknown major locus for deep-seated fluid escape

86 close to the center of the high resolution 3-D reflection seismic volume (Figs. 1B and

87 2A). The locus of this fluid escape is indicated by a $500 \mathrm{~m}$ diameter pockmark crater of

88 probable Holocene age mapped on the modern seabed (Fig. 2B, Fig. DR1). The

89 pockmark is the upper terminus of a vertical, cylindrical fluid escape pipe, directly

90 comparable to those seen in many other basins and generally interpreted to form by 
Publisher: GSA

Journal: GEOL: Geology

DOI:10.1130/G40219.1

91 hydraulic fracturing (Cartwright and Santamarina, 2015). Similar fluid escape pipes have

92 recently been identified crossing thick Messinian salt sheets offshore Egypt, where they

93 act as feeders for small mud volcanoes. These have also been attributed to hydraulic

94 fracturing (Kirkham et al. 2017), although dilatancy in the salt under high pressure may

95 contribute to the permeability of the pipe structure (c.f. Kukla et al. 2011). This c. $150 \mathrm{~m}$

96 wide, and > $2000 \mathrm{~m}$ tall pipe is interpreted to root in Early Miocene sandstone reservoirs

97 at the crest of a prominent NNE-SSW trending pre-salt anticline (Fold A)(Figs. 2A and

98 2B; Figs. DR1 and DR2). The pipe is interpreted from abrupt stratal reflection

99 terminations (see Data Repository) crossing mid-late Miocene claystones, Messinian

100 evaporites and Pliocene to Recent claystones. Acoustically soft amplitude 'soft'

101 anomalies adjacent to the pipe (Fig. 2D; Fig. DR2) are indicative of shallow gas

102 accumulations (Judd and Hovland, 2009). This is consistent with the pipe acting as a

103 conduit for gas during pipe formation, as is commonly observed in many other fluid

104 escape pipes and mud volcano conduits (Kirkham et al., 2017).

105 Volumetric interpretation of the coherence attribute volume (see Data Repository)

106 resulted in the identification of an additional 20 pockmarks of similar dimensions to the

107 modern pockmark (Fig. 2; Figs. DR2 and DR3). The 21 pockmarks are strongly aligned

108 (Fig. 2A; Fig. DR3), individually incising into successively younging seismic horizons in

109 a ESE direction (Fig. 2B, C and D). Each pockmark is underlain by a vertical zone of

110 stratal disruption that extends downwards within the post-salt overburden succession to

111 terminate within a zone of highly disrupted reflections within the Messinian Evaporites

112 (Figs. 2C and 2D). 
Publisher: GSA

Journal: GEOL: Geology

DOI:10.1130/G40219.1

113 Trails of amplitude anomalies observed in horizontal slices within the evaporite

114 units in the root mean square (RMS) amplitude volume match the trail seen in horizontal

115 slices through the coherence attribute volume (Fig. DR3). The disrupted intra-Messinian

116 seismic reflections beneath the linearly aligned pockmark trail are bounded by a single,

117 continuous, gently curved reflection (Reflection X) that dips at an average of $16^{\circ}$ from a

118 position directly beneath the oldest pockmark to the crest of the anticline at the Base Salt

119 horizon (Fig. 2B; Fig. DR1). This inclined reflection is narrow, measuring c. $150 \mathrm{~m}$

120 across on profiles extracted from the volume on trajectories orthogonal to the pockmark

121 trail. The narrow width of this inclined Reflection X means that it cannot be interpreted

122 as one of the many intra-Messinian shear zones that are widely developed in the Levant

123 Basin (Fig. 2B; Fig. DR2). These typically extend for many kilometres along their strike

124 (Cartwright et al., 2012; Gvirtzman et al., 2013). Seismic profiles from either side of the

125 pockmark trail show a remarkably consistent intra-Messinian deformational geometry

126 (Fig. DR2). This implies that the seismic character of both Reflection X and the

127 immediately overlying evaporites represent an acoustic fabric that was superimposed on

128 the already deformed evaporites within the narrow corridor delimited by the pockmark

129 trail.

\section{DISCUSSION}

131 We interpret Reflection $\mathrm{X}$ as a deformed fluid expulsion pipe that was originally

132 vertical when it was emplaced at the time of formation of the first pockmark. We date the

133 formation of this fluid expulsion pipe as $1.7 \mathrm{Ma}(+/-0.3 \mathrm{Ma})$ by tracing the horizon

134 hosting the pockmark fed by this pipe to stratigraphically calibrated exploration 
Publisher: GSA

Journal: GEOL: Geology

DOI:10.1130/G40219.1

135 boreholes (see Data Repository). Subsequent flow of the Messinian Evaporites led to

136 shearing of the pipe (Fig. 3).

137 By interpolation between the oldest and youngest pockmark, all intervening

138 pockmarks would also be linked to their own individual feeder pipes. Their trajectories

139 through the salt would also have been vertical at the time of formation, emanating from a

140 common point in the pre-salt at the shallowest depth of the underlying reservoir at the

141 absolute crest of the anticline (Fig. 3B). This common exit point of the fluids from the

142 deep reservoir into the salt and beyond is consistent with the lateral transfer of

143 overpressure, which predicts crestal bleed-off of overpressured cells (Flemings et al.,

144 2002). Subsequent shearing by salt flow would have been incrementally smaller for each

145 succeeding pockmark-pipe structure. This interpretation explains the lack of coherence in

146 the reflection character of the interval overlying Reflection X, and the trail of amplitude

147 anomalies seen on horizontal RMS amplitude slices through the salt (Fig. 2B; Fig. DR3).

148 The deformed pipe geometry demonstrates conclusively that the overburden was

149 fully coupled to the salt throughout the Pliocene to Recent with no detachment. The

150 rooting of 21 separate pipes to the crest of the anticline strongly implies that the flow

151 within the salt approached a velocity of zero at its base, and hence that there was no

152 localized detachment at the base of the salt. The flow direction is implicit from the

153 orientation of the pockmark trail. This WNW orientation of flow is independently

154 validated by orientations of fold axes in the nearby contractional domain immediately

155 downdip of the trail and strike data for fault planes mapped in the updip extensional

156 domain (Cartwright and Jackson, 2008)(Fig. 1B). 
Publisher: GSA

Journal: GEOL: Geology

DOI:10.1130/G40219.1

158 for salt tectonics that have not previously been quantified on a geological time scale.

159 Firstly, by dating the oldest pockmark in the trail, and recording the flow distance over

160 that time interval, the flow velocity of the upper boundary of this thick salt sheet can be

161 calculated to be $2(+/-0.3) \mathrm{mm} / \mathrm{a}$. Secondly, the geometry of the frontal deformed pipe

162 records the cumulative strain in the flow direction, and this provides a direct constraint on

163 the dominant mode of the flow regime operative during this interval of c. 1.7 Ma. The

164 gently curved geometry of this deformed pipe closely approximates pure Couette Flow,

165 although it should be noted that this geometry is subject to the usual limitations of

166 seismic resolution, and any minor irregularities in the flow profile would probably be

167 smoothed by the seismic imaging. Nevertheless, had there been a substantial component

168 of flow driven by body forces (Poiseulle), a distinctively more parabolic geometry would

169 be expected (Weijermars and Jackson, 2014). Couette flow is expected to occur where

170 the salt deformation is dominantly driven by shear traction imposed from a translating

171 overburden that is detached upslope, which in the case of the Levant Basin is achieved by

172 the activity of an array of growth faults coupled to the general westward tilting of the

173 basin (Cartwright and Jackson, 2008).

174 The average velocity measured for the top surface of the salt sheet allows us to

175 compute the shear strain rate $\left(4.10^{-14}\right)$ and the dynamic viscosity $\left(2.3 .10^{18} \mathrm{~Pa}\right.$ s) (see Data

176 Repository) both of which are average values for the c. 1.7 Ma time period represented

177 by the fluid escape pipes. These values are within the range of values for strain rate and

178 dynamic viscosity derived from studies of salt diapirs and salt extrusions, and from

179 laboratory-derived flow laws for common evaporite minerals (Urai and Spiers, 2007; 
Publisher: GSA

Journal: GEOL: Geology

DOI:10.1130/G40219.1

180 Urai et al., 2008). The viscosity value is based on the assumption of a Newtonian

181 rheology, a homogeneous salt composition, a constant tilt of the top salt based on the

182 present day value, and constant temperature within the salt, all of which grossly simplify

183 the likely natural conditions (see Urai et al., 2008). Nevertheless, this does not diminish

184 the potential value of identifying a strain marker within the salt sheet at the scale that

185 allows its full vertical kinematic evolution to be constrained.

186 The highly overpressured conditions described here for the formation of these

187 fluid escape pipes are by no means exceptional or unique in regions with thick salt

188 deposits (Bertoni et al., 2017). Deformed fluid escape pipes should therefore be expected

189 to occur elsewhere in the Messinian salt basin, and in other salt basins. The recognition of

190 this new class of exceptionally large dimension strain markers represented by the

191 deformed fluid escape pipes described here, thus offers the prospect of much improved

192 constraints on the large-scale kinematics of deforming, basin-scale salt sheets and the

193 testing of theoretical and experimental models for low strain rate salt deformation on a

194 geological time scale.

195

196 CONCLUSIONS

197 1. Seismic data reveals a linear trail of 21 fluid escape pipes in the Levant Basin that

198 formed episodically over the last 1.7 Myrs due to overpressuring beneath the 1.5

199 km thick Messinian evaporites.

2002 2. The fluid escape pipes were deformed by WNW directed flow of the salt sheet

201 after they formed, and hence represent a novel class of strain marker for

202 evaluation of salt kinematics. 
Publisher: GSA

Journal: GEOL: Geology

DOI:10.1130/G40219.1

203

\section{REFERENCES CITED}

219 Bertoni, C., and Cartwright, J.A., 2007, Major erosion at the end of the Messinian

3. The oldest deformed pipe has a gently curvilinear geometry suggesting the cumulative flow of the salt sheet over this period closely approximated Couette Flow, with top and base salt coupled to overburden and substrate, respectively.

4. The average flow velocity was $2 \mathrm{~mm} / \mathrm{yr}$, which equates to a shear strain rate of $4.10^{-14}$ and a viscosity of $2 \cdot 3 \cdot 10^{18} \mathrm{~Pa}$.

5. This is the first in situ measurement of salt sheet viscosity on a geological time scale, and lies within the range of experimentally predicted values.

\section{ACKNOWLEDGEMENTS}

We are grateful to the editor and reviewers Chris Talbot, Janos Urai and Peter Kukla for their insightful comments that led to improvements in the manuscript. Schlumberger are acknowledged for provision of the seismic interpretation software. Chris MacMinn and Martino Foschi are thanked for many helpful discussions. This paper is dedicated to the memory of Martin Jackson, mentor and true friend. Salinity Crisis: Evidence from the Levant Basin, Eastern Mediterranean: Basin Research, v. 19, p. 1-18, https://doi.org/10.1111/j.1365-2117.2006.00309.x.

Bertoni, C., Kirkham, C., Cartwright, J., Hodgson, N., and Rodriguez, K., 2017, Seismic indicators of focused fluid flow and cross-evaporitic seepage in the Eastern Mediterranean: Marine and Petroleum Geology, v. 88, p. 472-488, https://doi.org/10.1016/j.marpetgeo.2017.08.022. 
Publisher: GSA

Journal: GEOL: Geology

DOI:10.1130/G40219.1

226 Brun, J.P., and Fort, X., 2011, Salt tectonics at passive margins: Geology versus models:

227 Marine and Petroleum Geology, v. 28, p. 1123-1145,

228 https://doi.org/10.1016/j.marpetgeo.2011.03.004.

229 Cartwright, J.A., and Jackson, M.P.A., 2008, Initiation of gravitational collapse of an

230 evaporite basin margin: The Messinian saline giant, Levant Basin, eastern

Mediterranean: Geological Society of America Bulletin, v. 120, p. 399-413,

232 https://doi.org/10.1130/B26081X.1.

233 Cartwright, J., Jackson, M., Dooley, T., and Higgins, S., 2012, Strain partitioning in

234 gravity-driven shortening of a thick, multilayered evaporite sequence, in Alsop, G.I.

235 et al., eds., Salt Tectonics, Sediments and Prospectivity: Geological Society, London,

236 Special Publication 363, p. 449-470, https://doi.org/10.1144/SP363.21.

237 Cartwright, J., and Santamarina, C., 2015, Seismic characteristics of fluid escape pipes in

238 sedimentary basins: Implications for pipe genesis: Marine and Petroleum Geology,

239 v. 65, p. 126-140, https://doi.org/10.1016/j.marpetgeo.2015.03.023.

240 Feng, Y.E., Yankelzon, A., Steinberg, J., and Reshef, M., 2016, Lithology and

241 characteristics of the Messinian evaporite sequence of the deep Levant Basin, eastern

242 Mediterranean: Marine Geology, v. 376, p. 118-131,

243 https://doi.org/10.1016/j.margeo.2016.04.004.

244 Flemings, P.B., Stump, B.B., Finkbeiner, T., and Zoback, M., 2002, Flow focusing in

245 overpressured sandstones: Theory, observations, and applications: American Journal

246 of Science, v. 302, p. 827-855, https://doi.org/10.2475/ajs.302.10.827. 
Publisher: GSA

Journal: GEOL: Geology

DOI:10.1130/G40219.1

247 Gemmer, L., Ings, S.J., Medvedev, S., and Beaumont, C., 2004, Salt tectonics driven by

248 differential sediment loading: stability analysis and finite element experiments: Basin

249 Research, v. 16, p. 199-218, https://doi.org/10.1111/j.1365-2117.2004.00229.x.

250 Gradmann, S., Hübscher, C., Ben-Avraham, Z., Gajewski, D., and Netzeband, G., 2005,

251 Salt tectonics off northern Israel: Marine and Petroleum Geology, v. 22, p. 597-611,

252 https://doi.org/10.1016/j.marpetgeo.2005.02.001.

253 Gvirtzman, Z., Reshef, M., Buch-Leviatan, O., and Ben-Avraham, Z., 2013, Intense salt

254 deformation in the Levant Basin in the middle of the Messinian Salinity Crisis: Earth

255 and Planetary Science Letters, v. 379, p. 108-119,

256 https://doi.org/10.1016/j.eps1.2013.07.018.

257 Jackson, M.P.A., and Hudec, M.R., 2017, Salt Tectonics: Principles and Practice.

258 Cambridge, UK, Cambridge University Press, 510 p,

259 https://doi.org/10.1017/9781139003988.

260 Judd, A., and Hovland, M., 2009, Seabed fluid flow: the impact on geology, biology and

261 the marine environment: Cambridge, UK, Cambridge University Press, 492 p.

262 Kirkham, C., Cartwright, J., Hermanrud, C., and Jebsen, C., 2017, The genesis of mud

263 volcano conduits through thick evaporite sequences: Basin Research, v. 30, p. $217-$

$264 \quad 236$, doi.org/10.1111/bre.12250.

265 Kukla, P.A., Reuning, L., Becker, S., Urai, J.L., Schoenherr, J., 2011, Distribution and

266 mechanisms of overpressure generation and deflation in the Late Neoproterozoic to

267 Early Cambrian South Oman Salt Basin. Geofluids, v. 11, p. 349-361, doi:

$268 \quad 10.1111 / \mathrm{j} .1468-8123.2011 .00340 . \mathrm{x}$

Page 12 of 15 
Publisher: GSA

Journal: GEOL: Geology

DOI:10.1130/G40219.1

269 Li, S., Abe, S., Urai, J., Strozyk, F., Kukla, P. and Van Gent, H., 2012, A method to

270 evaluate long-term rheology of Zechstein salt in the Tertiary, in Berest, P., Goreychi,

271 M., Hadj-Hassen, F., Tijani, M., eds., SaltMech7 - The mechanical behaviour of salt

272 VII: London, Taylor and Francis, p. 215-220.

273 Reiche, S., Hübscher, C., and Beitz, M., 2014, Fault-controlled evaporite deformation in

274 the Levant Basin, Eastern Mediterranean: Marine Geology, v. 354, p. 53-68,

$275 \quad$ https://doi.org/10.1016/j.margeo.2014.05.002.

276 Urai, J.L. and Spiers, C.J., 2007, The Effect of Grain Boundary Water on Deformation

277 Mechanisms and Rheology of Rocksalt During Long-Term Deformation, in Wallner,

278 M., Lux, K., Minkley, W. and Jr., H.H. eds., Proceedings of the $6^{\text {th }}$ Conference on

279 the Mechanical Behaviour of Salt: Taylor and Francis, London, p. 149-158.

280 Urai, J.L., Schléder, Z., Spiers, C.J. and Kukla, P.A., 2008, Flow and Transport

Properties of Salt Rocks, in Littke, R., Bayer, U., Gajewski, D. and Nelskamp, S., eds., Dynamics of Complex Intracontinental Basins: The Central European Basin

System: Springer-Verlag, Berlin, Heidelberg, p. 277-290.

284 Weijermars, R., and Jackson, M.P., 2014, Predicting the depth of viscous stress peaks in

moving salt sheets: Conceptual framework and implications for drilling: The American Association of Petroleum Geologists Bulletin, v. 98, p. 911-945, https://doi.org/10.1306/09121313044.

289 FIGURE CAPTIONS

290 
Publisher: GSA

Journal: GEOL: Geology

DOI:10.1130/G40219.1

291 Figure 1. Stratigraphy of the North Levant Basin and deformation pattern of the

292 Messinian salt sheet. A: Location of the study area on a bathymetric map of the Eastern

293 Mediterranean, with locations of exploration wells used for calibration. B: Map of the

294 extensional domain and folds in the Plio-Pleistocene offshore Lebanon. C: Stratigraphic

295 column of the Neogene in the study area. D: Cross-section through the extensional and

296 contractional domains of the North Levant Basin. Sf - Seafloor; M - Top Salt; N - Base

297 Salt; BMM - Base Mid Miocene; OU - Oligocene Unconformity.

299 Figure 2. Seismic characteristics of multi episode fluid escape from a single locus. A:

300 Base Mid Miocene (BMM) contour map of NNE-SSW oriented fold and the location of

30121 linearly distributed pockmarks (PM) that overly. B: Seismic profile through the linear

302 trail of pipes (P). C: Seismic profile through a single pipe in the linear trail. D: Seismic

303 profile oblique to the pipe trail through nearby amplitude anomalies (AA). TAA - Trail

304 of amplitude anomalies; M - Top Salt; N - Base Salt; X - Reflection X; G/C B -

305 Gelasian/Calabrian boundary.

306

307 Figure 3. Geological evolution of the trail of deformed fluid escape pipes. A: At 1.7 Ma,

308 initial pipe $(\mathrm{P})$ propagates from a folded Early Miocene reservoir and transects the

309 overlying units, terminating in a pockmark (PM) at the seafloor (Sf). B: Subsequent pipes

310 are located above crest of Fold A but are deformed during continuous salt flow (dotted

311 lines). C: Present Day: linear trail of 21 pipes defines a progressive internal deformation

312 of the salt sheet by Couette Flow. M - Top Salt; N - Base Salt; BMM - Base Mid

313 Miocene; OU - Oligocene Unconformity; X - Reflection X. 
Publisher: GSA

Journal: GEOL: Geology

DOI:10.1130/G40219.1

314

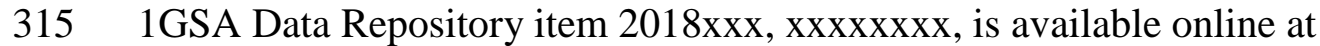

316 http://www.geosociety.org/datarepository/2018/ or on request from

317 editing@geosociety.org. 

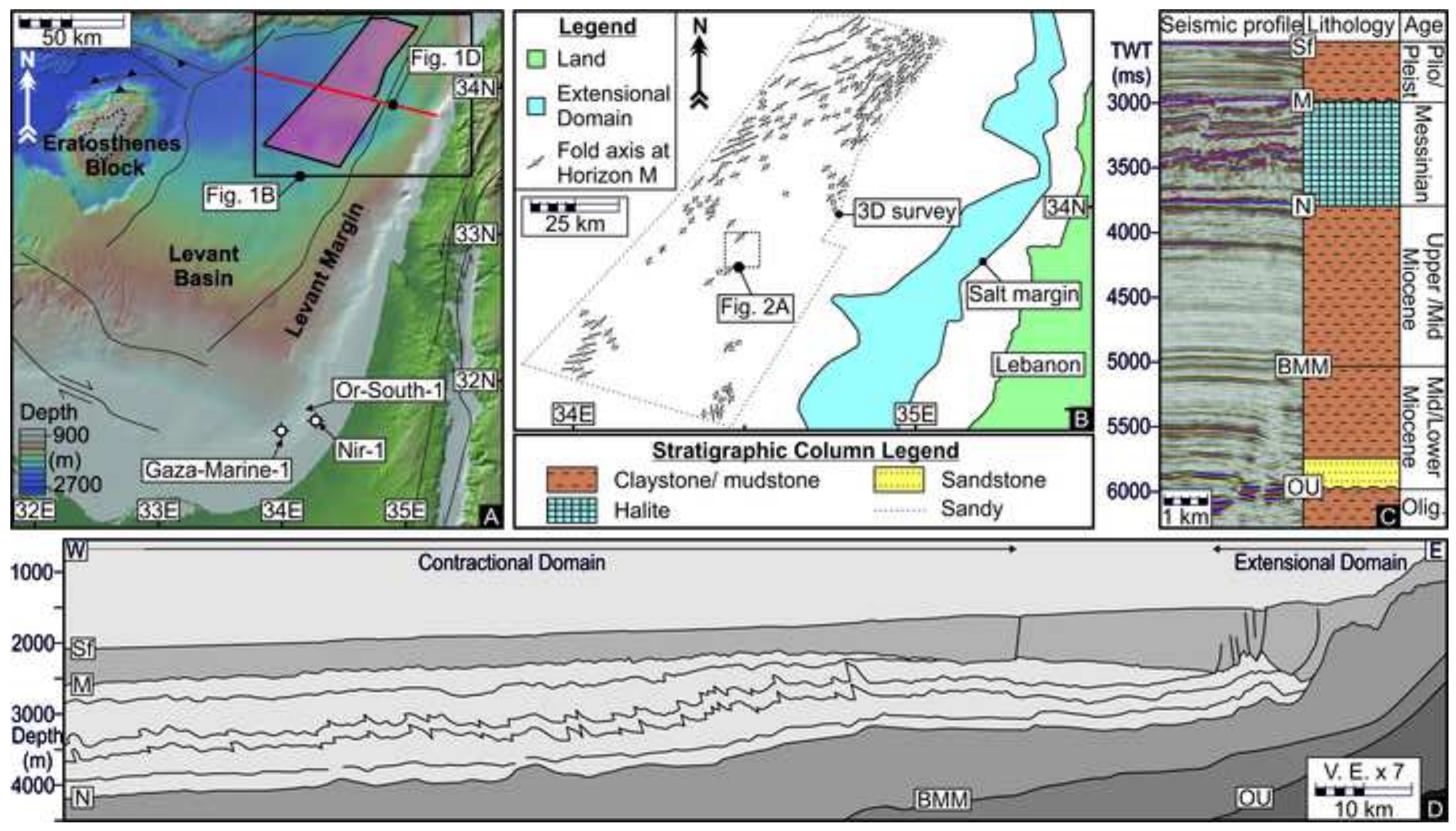

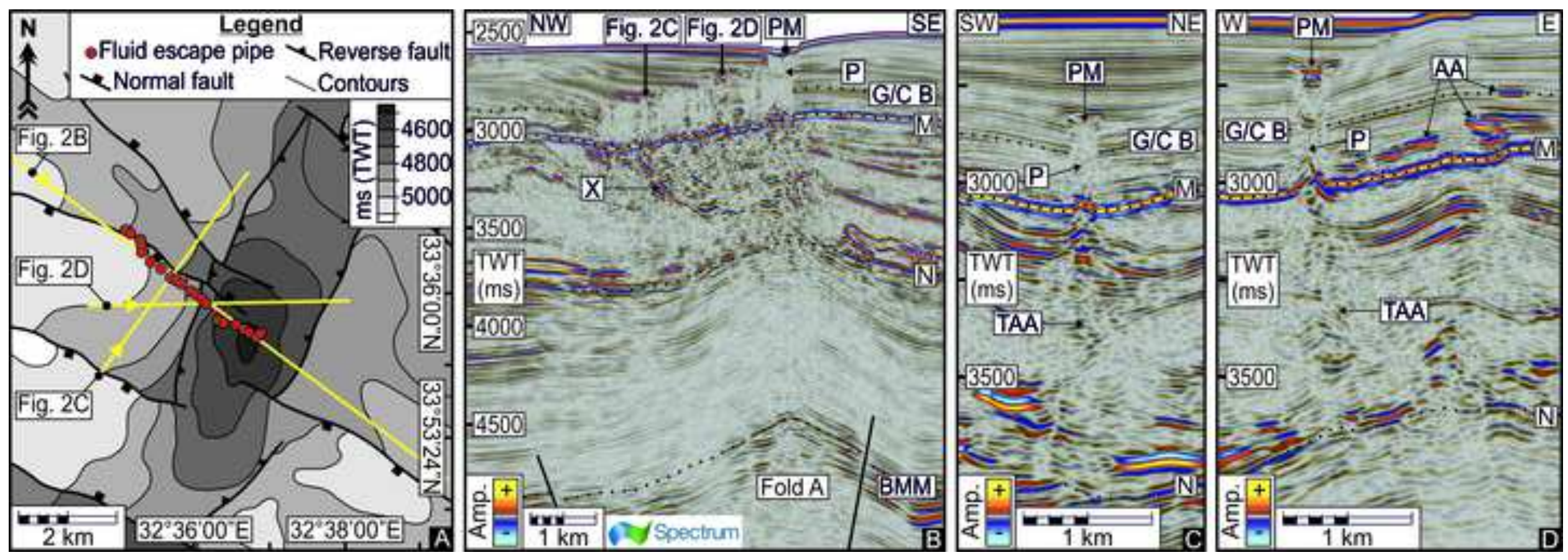

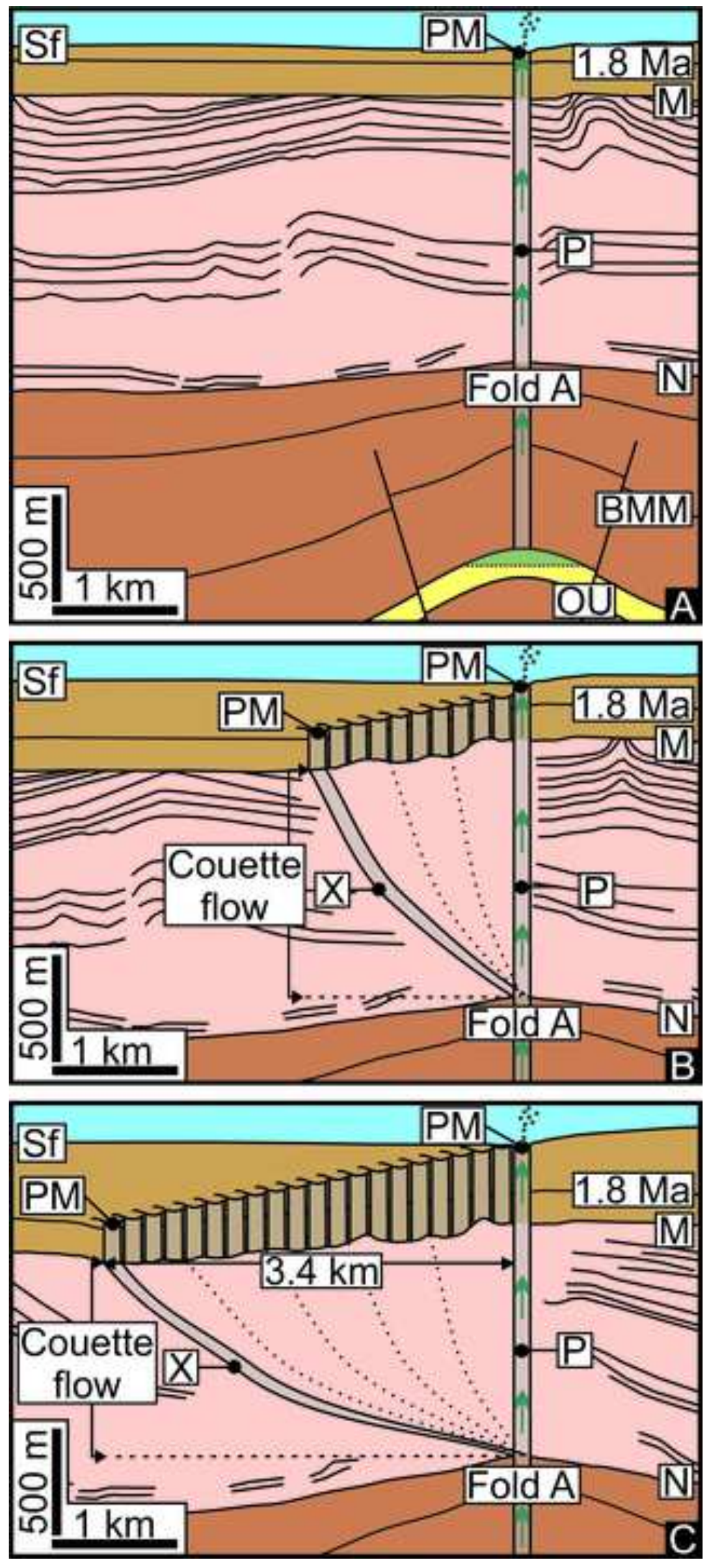
GSA DATA REPOSITORY

\section{Supplementary material for "Direct calibration of salt sheet kinematics during gravity-driven deformation"}

Joe Cartwright ${ }^{1}$, Chris Kirkham ${ }^{1}$, Claudia Bertoni ${ }^{1}$, Neil Hodgson ${ }^{2}$ and Karyna Rodriguez $^{2}$.

\section{Seismic and well database}

The data volume is post-stack time migrated, processed to a zero phase wavelet, and displayed with a polarity such that acoustically hard reflections (increase of acoustic impedance downwards) appear as positive amplitudes. The bin spacing is $12.5 \mathrm{~m}$ giving an effective lateral resolution of $25 \mathrm{~m}$ in the interval of interest. Dominant frequency is 50 and $30 \mathrm{~Hz}$ in the post-Messinian and Messinian intervals, respectively. The average $\mathrm{P}$ wave velocity for the post-Messinian interval is $2,000 \mathrm{~m} / \mathrm{s}$ (based on nearby exploration wells Or-South-1, Nir-1 and Gaza-Marine-1; Fig. 1A; Fig. DR4) resulting in a vertical resolution of $10 \mathrm{~m}$, based on the standard quarter wavelength criterion (Brown, 2011). The $\mathrm{P}$ wave velocity for the Messinian of 4,200 $\mathrm{m} / \mathrm{s}$ is taken from exploration wells that drilled through the salt sheet to the southwest of the study area (Feng et al., 2016) giving a vertical resolution of $35 \mathrm{~m}$ within the salt. These velocities were used for depth conversion, along with an estimated 3,000 $\mathrm{m} / \mathrm{s}$ for the pre-Messinian interval. Stratigraphic calibration of the key marker horizons in the $3 \mathrm{D}$ seismic survey were provided by long range correlations to exploration boreholes Or-South-1, Nir-1 and Gaza-Marine-1 (Fig. DR4). 


\section{Interpretation criteria for identification of pockmarks and fluid escape pipes}

Pockmark craters were interpreted according to standard seismic interpretation criteria including a circular planform, crater-like morphology and incision at their base (Judd and Hovland, 2009). The absence of any seismically resolvable fill in the seafloor pockmark was used to infer a probable Holocene age (c.f. Reiche et al., 2014). Fluid escape pipes were interpreted based on diagnostic seismic features including loss of reflection coherency in a cylindrical zone, anomalous amplitude reflections within and immediately surrounding the pipe, and an upper termination in a pockmark crater (Moss and Cartwright, 2010; Cartwright and Santamarina, 2015)(Fig. 2; Figs. DR2 \& DR3). Imaging challenges for interpreting fluid escape pipes within thick salt layers were taken into account (Kirkham et al., 2017) and contribute to positioning uncertainties for the calculation of flow velocity. This primarily affects the detailed measurement of pipe diameter, rather than the center points of pipes or pockmarks. Reflection X (Fig. 2) was interpreted by connecting the most frontal circular amplitude anomaly identified on closely spaced amplitude slices through the volume. Each circular anomaly was digitised for each slice, and an interpolation routine was used to connect the individual anomaly outlines into a volumetric body (Fig. DR1).

\section{Dating key seismic horizons}

Marker horizons were correlated to petroleum exploration wells further south in the basin using the 3D seismic data and a regional 2D seismic survey (Fig. DR4). The nearest boreholes that provide an age calibration for the important marker defining the 
formation of the earliest pockmark are Nir-1, Or-South-1 and Gaza-Marine-1 offshore Gaza, some $240 \mathrm{~km}$ to the south (Fig. 1; Fig. DR4). The well ties indicate a Calabrian age for this onset marker horizon (c. $1.7+/-0.3 \mathrm{Ma}$ ), based on calibration of the Gelasian-Calabrian boundary. The boundary is dated at 1.806 My (Gradstein et al., 2012), and was identified in biostratigraphic well reports through the recognition of index taxa. The shallowest and last occurrence of $D$. brouweri is a regional marker for the top of Zone NN18 (1.95 Ma)(Catalano et al., 1998). The lowermost section of the Calabrian is defined by the downhole decrease in the recovery of Gephyrocapsa spp. (Rio et al., 1997) and the first occurrence of G.tenellus, B. etnea and H. baltica (Barbieri et al., 1998). These observations define the Gelasian-Calabrian boundary on seismic data within a range of error of approximately 150 ky (Fig. DR4). The uncertainty reflects the errors implicit in long range seismic correlation and in correctly picking the zonal fossils used to date the horizon. The top and base of the Messinian Evaporites are confidently identified by correlation to well ties in the area of the Tamar Field, some $60 \mathrm{~km}$ to the southwest (Feng et al., 2016)(Fig. 1a).

\section{Salt Flow Kinematics}

The average flow velocity for the upper boundary of the salt sheet was calculated from the biostratigraphic date for the horizon incised by the earliest pockmark, and the horizontal distance between the earliest and latest pockmark craters $(3.4 \mathrm{~km})($ Fig. DR1). These values give an average flow velocity of $2(+/-0.3) \mathrm{mm} / \mathrm{a}$ over the past 1.7 myrs. The shear strain rate of $4.23 .10^{-14}$ was calculated from the average velocity divided by the salt sheet thickness $(1500 \mathrm{~m})$, making the important assumption that the sheet did not thin during this time interval. The dynamic viscosity was calculated 
by dividing the shear stress by the shear strain rate (Barnes et al., 1989), assuming a Newtonian rheology and homogenous composition for the salt sheet. Both of these assumptions are questionable, although at low temperature, and slow strain rate the salt deformation could be expected to be dominated by solution-precipitation creep which would be consistent with a Newtonian rheology (Jackson and Hudec, 2017). Thin interbeds of claystones have been inferred within the salt from analysis of petrophysical logs acquired in exploration boreholes further south in the basin (Feng et al. 2016), and these would certainly influence the gross behaviour of the salt. We also assumed a constant temperature profile through the salt, which is a gross simplification, but have no data on temperature variations within, above or below the salt.

The salt was assumed to deform dominantly by shear traction at the upper boundary of the salt sheet, consistent with the idealised boundary conditions for Couette Flow (Weijermaars and Jackson, 2014). Shear stress was calculated for a present day overburden tilt of $0.7^{\circ}$ measured from a depth converted seismic profile (Fig. 1D) using a standard analytical approach for Couette Flow (Weijermaars and Jackson, 2014) and assuming an overburden thickness of $400 \mathrm{~m}$ (present day), and a density averaging $2000 \mathrm{~kg} / \mathrm{m}^{3}$. Earlier pipes may have formed with tilt angles different from that today, and we assumed a range of 0.1 to $2^{\circ}$ based on analysis of the reflection configurations and isopach patterns in the Late Pliocene to Pleistocene interval. These values yielded viscosity values ranging from $3.22 .10^{17}$ to $6.6 .10^{18} \mathrm{~Pa}$.s (present day value is $2.27 .10^{18} \mathrm{~Pa} . \mathrm{s}$ ) which is within the range quoted from theoretical and field studies of evaporites dominantly composed of halite (Jackson and Hudec, 2017) 


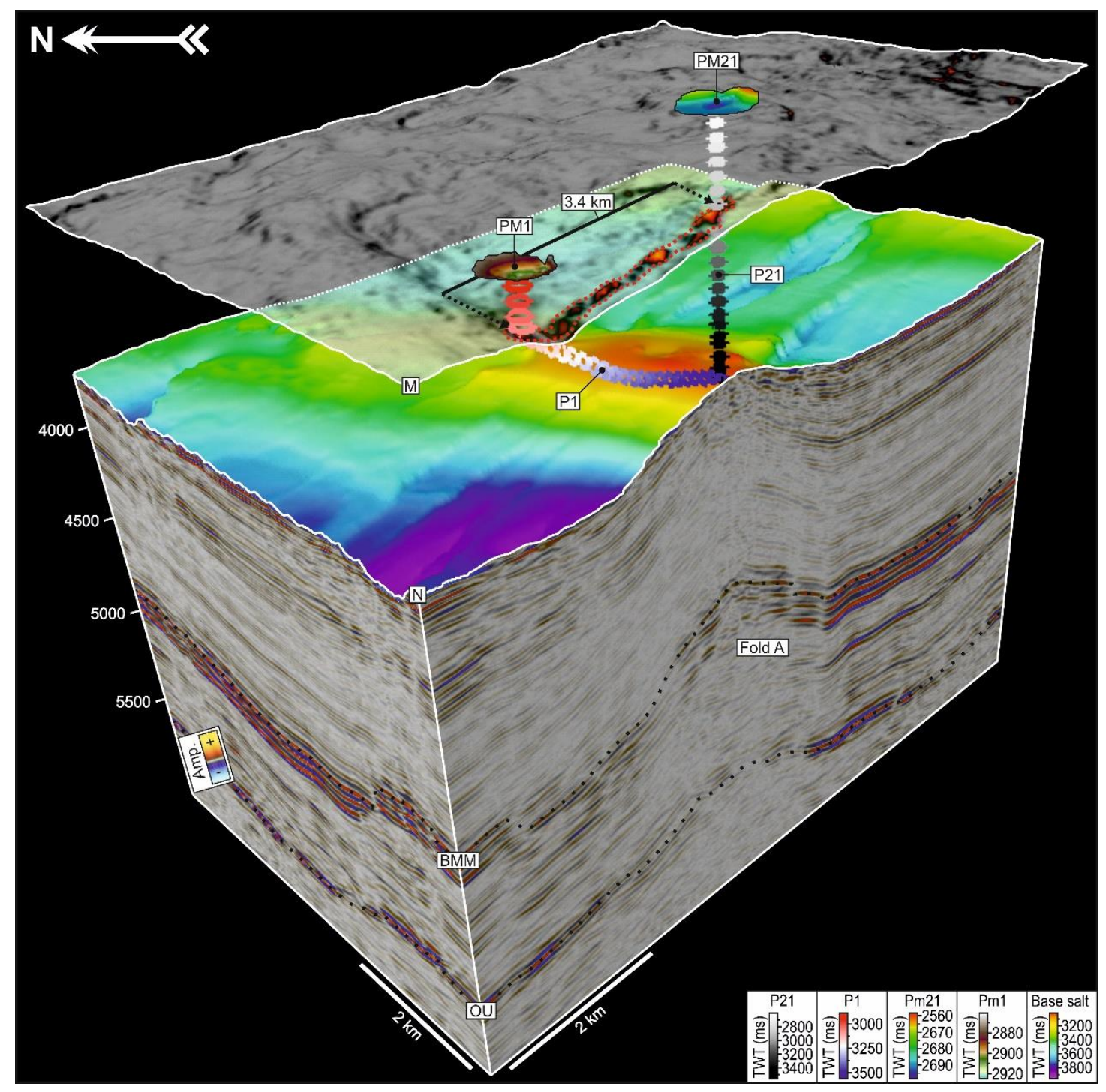

Figure DR1: A three dimensional block model of the first and most recent fluid escape pipes ( $\mathrm{P} 1$ and $\mathrm{P} 21$ ), emanating from the crest of the anticline Fold A. The pipes terminate at pockmarks located at individually specific stratigraphic levels, successively younging towards the ESE. The distance between the first and most recent pockmarks is $3.4 \mathrm{~km}$. The trail of pipes produces a WNW-ESE oriented trail of reflection discontinuity as exhibited in the variance extraction map of the top surface of the evaporites (M) and highlighted by the red dotted outline. Three dimensional mapping of the pipes through the salt displays a columnar structure for the most recent pipe (P21) and a gently curvilinear geometry to the first pipe (P1) that closely approximates that which would be expected from Couette Flow through the salt. OU - 
Oligocene Unconformity; BMM - Base Mid Miocene; N - Base salt; PM1 Pockmark 1; PM21 - Pockmark 21. 


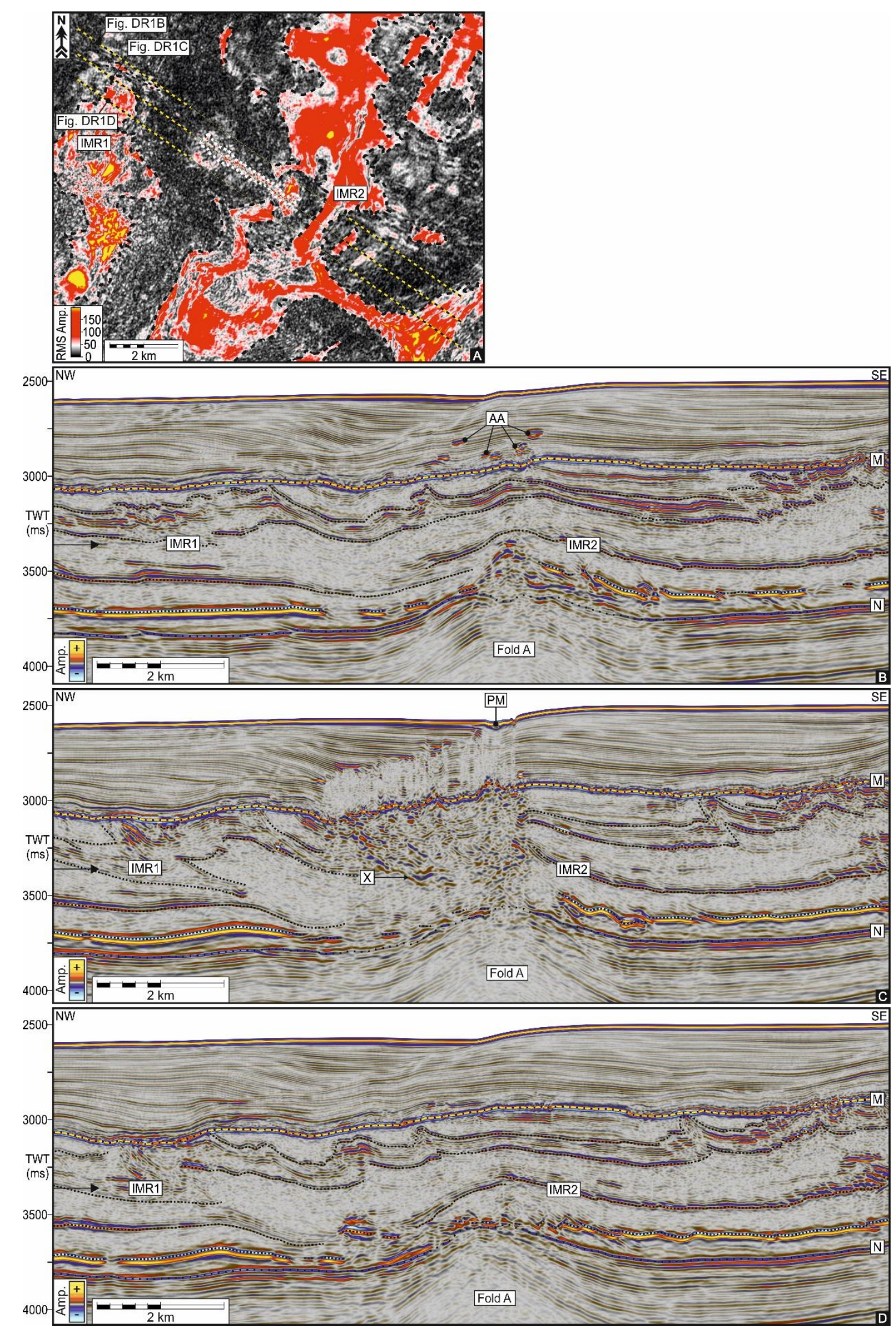

Figure DR2: Seismic profiles 500 m either side of the pockmark trail and Reflection

$\mathrm{X}$, demonstrating that the geometry of intra-salt reflections is similar on both sides 
and contrasts with the geometry of Reflection $\mathrm{X}$. Reflection $\mathrm{X}$ was hence superimposed over an already deformed evaporitic succession.

(A) An RMS amplitude slice (3363 ms (see black arrow on seismic profiles); Fig. DR2B-D for position of slice) through the pipe trail in the salt (highlighted by white dotted line) and numerous intra-Messinian stratal anomalies (highlighted by black dashed line). The lines of section for Fig. DR2B-D are displayed and the deformed intra-Messinian reflections (IMR1 and IMR2) that these seismic profiles intersect are highlighted. (B) A seismic profile $500 \mathrm{~m}$ to the northeast of the pipe trail exhibiting numerous reflective layers within the evaporitic succession. Fold A is present within the seismic profile; however no fluid escape pipes are visible within the evaporitic or Plio-Pleistocene sequences. The intra-Messinian reflections highlighted in Fig. DR2A (IMR1 and IMR2) are also highlighted here. Several amplitude anomalies (AA) that are acoustically soft are displayed within the Plio-Pleistocene. (C) A seismic profile through the pipe trail that shows an area of vertical discontinuities within the PlioPleistocene which is underlain by an acoustic fabric and the coherent reflection of Reflection $\mathrm{X}$, which is discordant to the intra-Messinian reflections. The intraMessinian reflections highlighted in Fig. DR2A are also highlighted here (IMR1 and IMR2). (D) A seismic profile $500 \mathrm{~m}$ to the southwest of the pipe trail that exhibits numerous intra-Messinian reflections (also highlighted in Fig. DR2A) that display similar geometries to the cross-section in Fig. DR2B and shows no evidence of the fluid escape pipes, acoustic fabric or Reflection X seen in Fig. DR2C. M - Top salt; N - Base salt. 

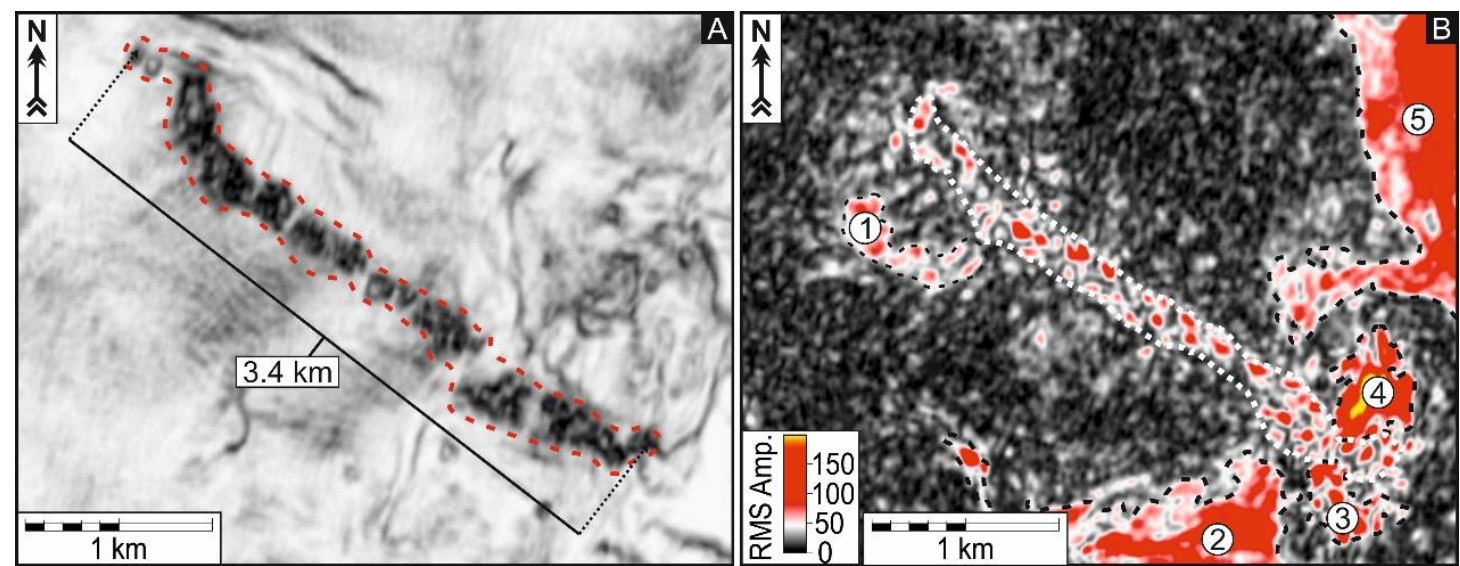

Figure DR3: (A) A WNW-ESE oriented distribution of fluid escape pipes in the Pliocene to Recent, expressed in a horizontal slice of the coherence attribute volume (2912 ms) as a linear trail of circular to sub-circular discontinuities (highlighted by red dashed line). (B) An RMS amplitude horizontal slice (3364 ms) through the evaporitic unit at the exact same spatial location as in Fig. DR3A. The fluid escape pipes appear as a localised WNW-ESE oriented trail of amplification (highlighted by white dotted line). Intra-salt stratal anomalies (labelled 1-5 and highlighted by black dashed lines) exhibit contrasting geometrically irregular areas of high amplitude. 


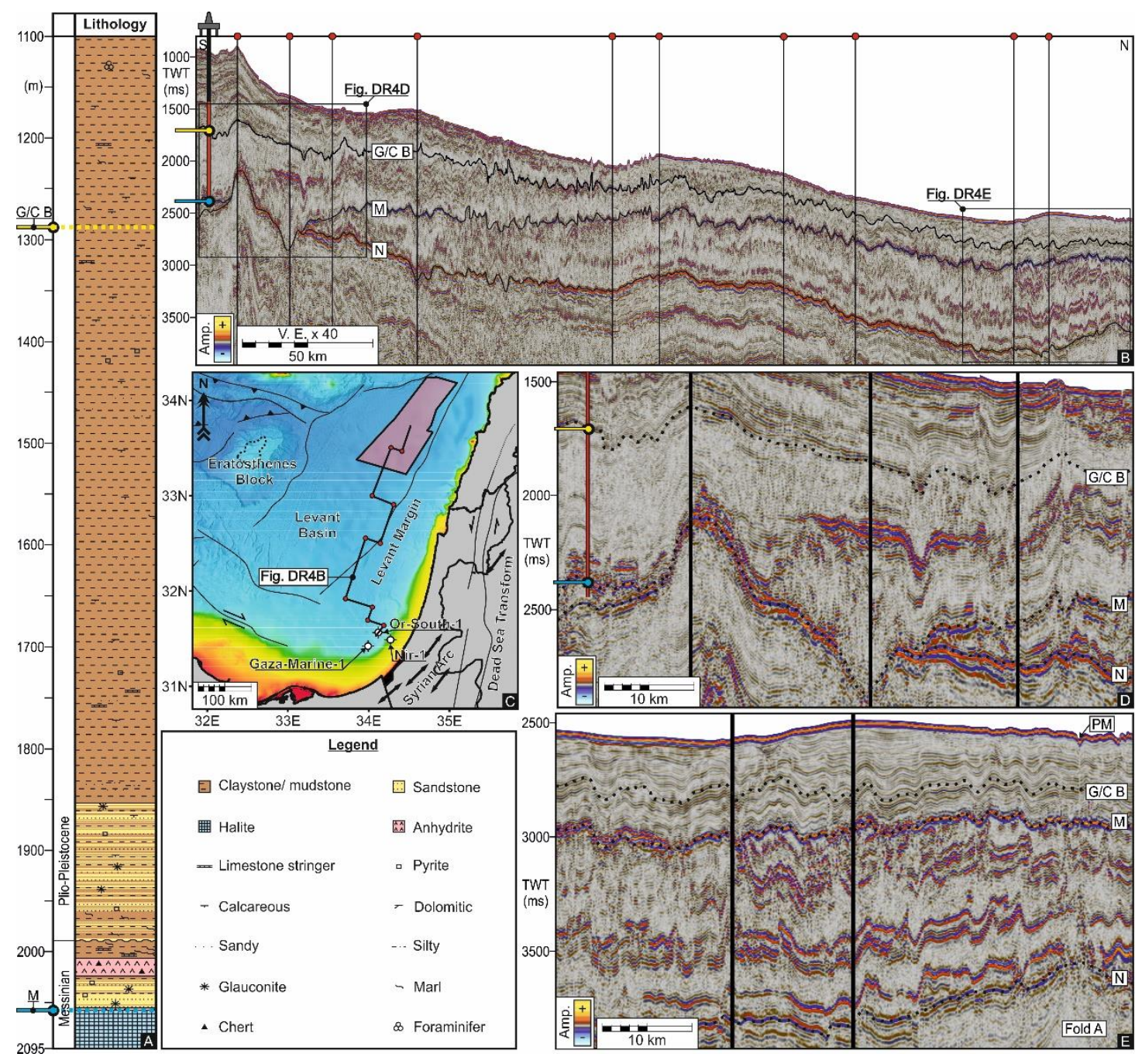

Figure DR4: Seismic to well tie. The well data aided the calibration of the top of the salt (M) and of the Gelasian/Calabrian boundary $1.806 \mathrm{Ma}(\mathrm{G} / \mathrm{C} \mathrm{B})$. (A) A section of the stratigraphic column from the Or-South-1 well that extends from a depth of 1100 $\mathrm{m}$ within the Pleistocene to a total depth of $2095 \mathrm{~m}$ where it terminates in the evaporites. The well shows detailed lithological variation and the boundaries between the top of the salt (M) and the Plio-Pleistocene sequences, and the boundary between the Gelasian and Calabrian. (B) A composite seismic cross-section (see Fig. DR4C for location) that extends from the South Levant Basin to the 3D seismic survey area in the North Levant Basin and shows the long range calibration of key marker horizons from the Or-South-1 well. (C) Map of the Levant Basin that displays the location of the 3D seismic study area offshore Lebanon, and the location of the Gaza-Marine 1, 
Nir-1 and Or-South-1 wells in the South Levant Basin used for the well to seismic tie. The position of the composite line used in Fig. DR4B to demonstrate the long range calibration of key marker horizons is shown. (D) A zoomed-in (close up) seismic profile from the South Levant Basin (see Fig. DR4B for location) showing our interpretation of key marker horizons. (E) A zoomed-in seismic profile from the North Levant Basin (see Fig. DR4B for location) showing our interpretation of key marker horizons.

\section{REFERENCES}

Brown, A.R., 2011, Interpretation of three-dimensional seismic data: Society of Exploration Geophysicists and American Association of Petroleum Geologists, 665 p.

Barbieri, M, Castorina, F., Colalongo, M.L., Pasini, G., and Vaiani, S.C., 1998, Worldwide correlation of the Pliocene/Pleistocene GSSP at Vrica (Southern Italy) confirmed by strontium isotope stratigraphy: Newsletters on Stratigraphy, v. 36, p. $177-187$.

Barnes, H.A., Hutton, J.F. and Walters, K., 1989, An introduction to rheology (Vol. 3): Amsterdam, Elsevier, 200 p.

Catalano, R., Di Stefano, E., Sulli, A., Vitale, F. P., Infuso, S. \& Vail, P. R., 1998, Sequences and Systems Tracts Calibrated by High Resolution Bio- 
Chronostratigraphy: The Central Mediterranean Plio-Pleistocene Record: SEPM (Society of Sedimentary Geology) Special Publication, v. 60, p. 115-177,

Cartwright, J. and Santamarina, C., 2015, Seismic characteristics of fluid escape pipes in sedimentary basins: implications for pipe genesis: Marine and Petroleum Geology, v. 65, p. 126-140.

Feng, Y.E., Yankelzon, A., Steinberg, J. and Reshef, M., 2016, Lithology and characteristics of the Messinian evaporite sequence of the deep Levant Basin, eastern Mediterranean: Marine Geology, v. 376, p. 118-131.

Gradstein, F. M., Ogg, J. G., Schmitz, M., Ogg, G., 2012, The geologic time scale: Elsevier, 1176 p.

Jackson, M.P.A, and Hudec, M.R., 2017, Salt Tectonics: Principles and Practice: Cambridge, Cambridge University Press, 510 p.

Judd, A. and Hovland, M., 2009, Seabed fluid flow: the impact on geology, biology and the marine environment: Cambridge University Press, $492 \mathrm{p}$.

Kirkham, C., Cartwright, J., Hermanrud, C. and Jebsen, C., 2017, The genesis of mud volcano conduits through thick evaporite sequences: Basin Research, doi: 10.1111/bre.12250. 
Moss, J.L. and Cartwright, J., 2010, 3D seismic expression of km-scale fluid escape pipes from offshore Namibia: Basin Research, v. 22, p. 481-501.

Reiche, S., Hübscher, C. and Beitz, M., 2014, Fault-controlled evaporite deformation in the Levant Basin, Eastern Mediterranean: Marine Geology, v. 354, p. 53-68.

Rio, D., Raffi, I., Backman, J., 1997, Calcareous nannofossil biochronology and the Pliocene-Pleistocene boundary, in Van Couvering J.A., ed., The Pleistocene Boundary and the Beginning of the Quaternary, World and Regional Geology 9: Cambridge University Press, p. 64-79.

Weijermars, R. and Jackson, M.P., 2014, Predicting the depth of viscous stress peaks in moving salt sheets: Conceptual framework and implications for drilling: American Association of Petroleum Geologists Bulletin, v. 98, p. 911-945. 